\title{
FIGHTING THE WAVES
}

First performed at the Abbey Theatre

on $13^{\text {th }}$ August 1929

\author{
TO \\ HILDO VAN KROP \\ WHO MADE THE MASKS
}

\author{
PERSONS IN THE PLAY \\ Three Musicians \\ Cuchulain \\ The Ghost of Cuchulain \\ Emer \\ Eithne Inguba \\ The Figure of Cuchulain \\ The Woman of the Sidhe
}

Note: Fighting the Waves, a prose rewriting of The Only Jealousy of Emer, was printed in 83. The text below and on succeeding verso pages is from the English edition of 83. The collation of The Only Jealousy of Emer is on the recto pages. Similarities between the two versions are shown by bracketed line-numbers in the margin; identities by unbracketed line-numbers. Line lengths are the same as those in ${ }^{8} \mathbf{E}$. 